\title{
Screening global set of barley germplasm for resistance to spot blotch disease in the warm-humid plains of Nepal
}

Bhanu Bhakta Pokharel ${ }^{1 *}$, Madhav Prasad Pandey ${ }^{2}$, Surya Kant Ghimire ${ }^{2}$, Dhruba Bahadur Thapa ${ }^{1}$, Hira Kaji Manandhar ${ }^{3}$, Tirtha Raj Rijal ${ }^{4}$, Shailendra Thapa ${ }^{4}$, Parbati Adhikari ${ }^{4}$, Ramesh Pal Singh Verma $^{5}$ and Sanjay Gyawali ${ }^{6}$

${ }^{1}$ Nepal Agricultural Research Council (NARC), Kathmandu, Nepal

${ }^{2}$ Department of Genetics and Plant Breeding, Agriculture and Forestry University (AFU), Rampur, Chitawan, Nepal

${ }^{3}$ Department of Plant Pathology, AFU, Rampur, Chitawan, Nepal

${ }^{4}$ NARC, National Maize Research Program, Rampur, Chitawan, Nepal.

${ }^{5}$ International Center for Agricultural Research in the Dry Areas (ICARDA), Rabat, Morocco

${ }^{6}$ Biodiversity and Crop Improvement Program (BCI), ICARDA, Rabat, Morocco; Current Address: WSU, NSREC, 16650 State Route 536, Mt Vernon, WA98273, USA

\section{Article history:}

Received: 7 Jan., 2021

Revised: 24 March, 2021

Accepted: 15 April, 2021

\section{Citation:}

Pokharel BB, MP Pandey, SK Ghimire, DB Thapa, HK Manandhar, TR Rijal, S Thapa, P Adhikari, RPS Verma and S Gyawali. 2021. Screening global set of barley germplasm for resistance to spot blotch disease in the warm-humid plains of Nepal. Journal of Cereal Research 13(1): 70-78. http:// doi.org/10.25174/2582-2675/2021/111254

*Corresponding author:

E-mail: bhanu.pokharel@gmail.com

(C) Society for Advancement of Wheat and Barley Research

\begin{abstract}
Spot blotch disease (SB) caused by Bipolaris sorokiniana (teleomorph: Cochliobolus sativus) is a major disease of barley and causes a significant yield loss under favorable conditions in the warm and humid areas. A global set of 340 barley germplasm obtained from ICARDA were evaluated for SB resistance under natural epiphytotic conditions along with two local checks (Bonus and Solu Uwa) at the research field of Nepal Agricultural Research Council, Rampur, Chitawan, Nepal for three consecutive years (2016-2018). Analysis of variance showed significant variation in Area Under Disease Progress Curve (AUDPC) of the studied genotypes in all the three years' experiments. The check varieties were susceptible to SB (AUDPC value $\geq 750$ ) in all the experiments. In the first-year experiment, 28, 105, 98 and 109 genotypes had resistant $(R, A U D P C<250)$, moderately resistant $(M R$, AUDPC 250-499), moderately susceptible (MS, AUDPC 500-749), and susceptible $(S, A U D P C \geq 750)$ type of disease reaction, respectively. In the second year, 1, 42, 136 and 161 genotypes showed $R, M R, M S$, and $\mathrm{S}$ type of disease reaction. In the third-year, 69 genotypes had $\mathrm{MR}$, $132 \mathrm{MS}$ and $139 \mathrm{~S}$ type of disease reaction. Summarized across the years, about $27 \%$ genotypes had MS to MR or $\mathrm{R}$ type of SB reaction. The study identified barley lines that can be a potential source of SB resistance for barley breeding programs.
\end{abstract}

Key words:AUDPC, Bipolaris, disease severity, Hordeum vulgare, susceptible

\section{Introduction}

Barley (Hordeum vulgare L.) is one of the first cultivated food grains since human civilization. It is a major cereal grown in temperate climate with the production of 155.87 million $\mathrm{mt}$ across the world (FAO, 2019). Barley is primarily used for animal feed and to produce malt and alcoholic beverages (Tyagi et al., 2020; Patial et al., 2018). Also, it is a traditional food crop in East Africa, the
Highlands of Himalayas, Tibet, Andean countries and in the Baltic States (Baik and Ullrich, 2008). Because of the wider adaptability, resilient nature and recent findings of the health benefits of barley grains, there is a renewed importance of the crop as a human food (Newton et al., 2011; Idehen et al., 2017). In Nepal, barley is traditionally grown in small areas throughout the country. As a food 
Screening global set of barley germplasm for resistance to spot blotch disease in the warm-humid plains of Nepal

crop, it is common in the Himalayan highlands, especially in the western region where the production environments are harsh and food security is a major challenge (Pokharel et al., 2016). In these areas, Nepal government has emphasized promoting indigenous crops, such as barley for food security (MALD, 2019). However, lack of suitable high-yielding and disease-resistant varieties are the major concern for adoption of barley in these areas.

Spot blotch disease of barley caused by Bipolaris sorokiniana (teleomorph: Cochliobolus sativus) (SB hereafter) is an old disease (Bovill et al., 2010) and the pathogen is well-known as a causative agent of several diseases of cultivated and wild plants. SB is often a seed-borne disease but can also be caused by the conidia in the soil and air (Gupta et al., 2017). The pathogen overwinters on crop residues and releases spores in the spring and wind and rain disperse the spores (Gyawali et al., 2018). The infected seeds are the major source of inoculum (Pandey et al., 2008). The SB epidemics are higher in the areas characterized by average temperature above $17^{\circ} \mathrm{C}$ and high relative humidity during the crop season (Mudi et al., 2010; Mudi et al., 2016). The SB initially causes small, brown spots to appear on the leaves, sheaths, and glumes and these eventually expand into long, narrow, brown streaks striped with occasional deep brown lines across the lesions in a pattern that resembles a spot, yellow halo in the leaves (Manandhar et al., 2017). The diseased crop produces shriveled grains and decreased grain yield (Cane and Hampton, 1990) and the diseased grains degrade the quality of malt (Gyawali et al., 2018).

$\mathrm{SB}$ of barley is prevalent disease in the major barley cultivated area of the world, viz, Australia, Canada and United States (Knight et al., 2010; Gyawali et al., 2018) and causes significant yield loss, especially in the warm, humid production areas like that of North eastern Indo-Gangetic plains (Kumar et al., 2020), including Nepal. Yield loss of $10-30 \%$ is common when the weather condition is favorable for the disease development (Wang et al., 2017). The SB of barley can be controlled by fungicide applications (Devi et al., 2019; Kumar et al., 2014) but the use of resistant cultivar is the most economical and environment friendly approach for its control (Akhavan et al., 2016). The persistent challenge of SB disease in the warm humid environment requires an effective breeding program and diverse resistance sources. Hence, this study evaluated 342 global set of barley genotypes against SB disease and identified promising resistant germplasm lines.

\section{Materials and Methods}

\subsection{Barley genotypes}

A total of 342 barley genotypes that comprised of 340 diverse germplasm (Association mapping panel: AM-2014) obtained from the International Center for Agricultural Research in the Dry Areas (ICARDA) and two checks (Bonus and Solu Uwa) from Nepal were evaluated. The Nepalese barley varieties Bonus (tworowed, hulled type) and Solu Uwa (six-rowed, hull-less type) were developed and released for general cultivation in 1974 and 1990, respectively (NARC, 2020). These two checks are the only improved varieties currently grown in Nepal. The AM-2014 panel includes 230 genotypes from the ICARDA low input breeding program and 86 from the high-input breeding program. The other 24 genotypes were of mixed type. These include 280 hulled and 60 hullless type and based on row pattern 138 were two-row and 202 six-row type. In the AM-2014 panel, about 74\% were advanced breeding lines, 9.5\% were gene-bank accessions and $16.5 \%$ were barley varieties released by different breeding programs (India, Australia, USA, Canada, and Morocco). A detailed description of AM-2014 can be found in Amezrou et al. (2017).

\subsection{Field experiments}

Barley genotypes were evaluated in the research field of Nepal Agricultural Research Council, Rampur, Chitawan, Nepal. Rampur is situated at $84^{\circ} 20^{\prime} \mathrm{E}$ and $27^{\circ} 40^{\prime} \mathrm{N}$ and an altitude of 228-meter above the mean sea level. The location is characterized by a humid subtropical climate which is conducive for SB development (Figure 1). The experiment was laid out in augmented block design with two repeated checks. There were 17 blocks and 20 entries in each block. Planting was done on $4^{\text {th }}$ December 2015, $1^{\text {st }}$ December 2016, and $30^{\text {th }}$ November 2017. Each genotype was sown on $1.25 \mathrm{~m}^{2}$ plot (two rows of $2.5 \mathrm{~m}$ length). A row to row spacing was $25 \mathrm{~cm}$ and continuous seeding at the rate of $80 \mathrm{Kg} \mathrm{ha}^{-1}$ was practiced. Chemical fertilizers were applied @ $80 \mathrm{Kg} \mathrm{N}$ : $40 \mathrm{Kg} \mathrm{P}_{2} \mathrm{O}_{5}$ : and 30 $\mathrm{Kg} \mathrm{K}_{2} \mathrm{O}$ ha-1. Full doses of $\mathrm{P}_{2} \mathrm{O}_{5}$ in the form of diammonium phosphate and $\mathrm{K}_{2} \mathrm{O}$ in the form of muriate of potash were supplied at sowing. Nitrogen in the form of urea was applied thrice in equal splits at sowing, at crown root 
initiation, and booting stages. Irrigation was applied as and when needed to keep the field moist and conducive for disease development. Standard crop management practices were followed.

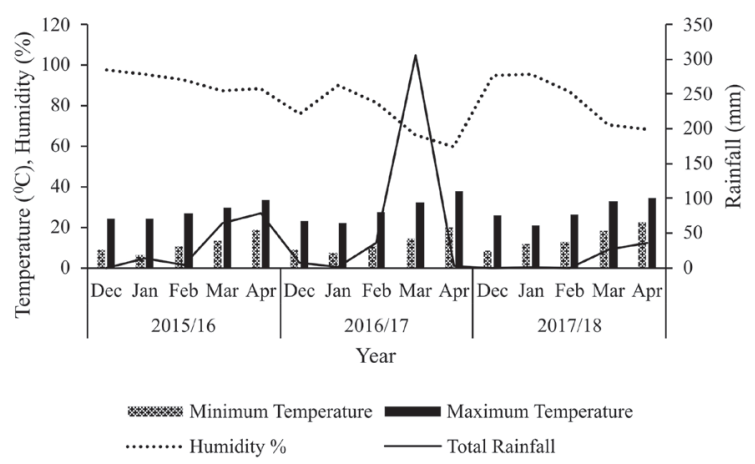

Figure 1. Weather data of the experimental field during the barley growing seasons of 2015-16, 2016-17 and 2017-18.

\subsection{Disease assessment}

Spot blotch disease observations were made during late boot stage, three times at ten days interval. Disease infection was scored using 1 to 9 scale (Saari and Prescott, 1975) and the double-digit scoring system (00-99) of Joshi et al. (2007). Disease severity was calculated by using the following formula (Turan et al., 2020).

Disease severity $(\%)=\left(\mathrm{D}_{1} / 9\right) \times\left(\mathrm{D}_{2} / 9\right) \times 100$

Where, first digit $\left(\mathrm{D}_{1}\right)$ shows the vertical progression of the disease in the plant and the second digit $\left(\mathrm{D}_{2}\right)$ indicates the disease severity. Area under the disease progress curve (AUDPC) was calculated using the following formula (Bocianowski et al., 2020).

$A U D P C=\sum_{i=1}^{n}\left\{\left(\frac{y_{i}+y_{i-1}}{2}\right)\left(x_{i}-x_{i-1}\right)\right\}$

Where, AUDPC is the area under disease progress curve, $y_{i}$ is the percentage of visible infected area $\left(y_{i} / 100\right)$ at the $\mathrm{i}^{\text {th }}$ observation, $\mathrm{x}_{\mathrm{i}}$ - day of the $\mathrm{i}^{\text {th }}$ observation, and $\mathrm{n}$ - the total number of observations.
As described by Joshi et al. (2007), the genotypes with AUDPC $<250$ were considered as resistant (R), 250-499 as moderately resistant (MR), 500-749 as moderately susceptible (MS) and $>750$ as susceptible (S).

\subsection{Statistical analysis}

The descriptive figure for the AUDPC data was obtained using Microsoft Excel. Analysis of variance for augmented design was carried out with the 'agricolae' package version 1.3-3 (Mendiburu, 2020), implemented in R environment (R Core Team, 2021).

\section{Results and Discussion}

The analysis of variance revealed highly significant differences $(\mathrm{p} \leq 0.001)$ among the entries for AUDPC in all the three years (Table 1). The two check varieties significantly differed for AUDPC values in 2017 and 2018 but not in 2016. The AUDPC of the 342 studied genotypes for 2016, 2017 and 2018; mean AUDPC and their disease reaction type (R, MR, MS or $S$ ) are presented in the supplementary Table S1. The frequency of genotypes with different reaction types for individual test year is given in Figure 2. The frequency of genotypes with MS and S type of reaction was higher in 2017 and 2018, whereas the genotypes with $\mathrm{R}$ and MR type of reaction was higher in 2016. Previous studies have shown variation in spot blotch (SB) severity and disease reaction type of barley genotypes across years (Singh et al., 2014) and under natural and artificial disease inoculum conditions (Singh et al., 2014). The conducive environment for SB disease in the test location (Figure 1) and the consistent susceptible disease reaction of the check varieties indicated that disease screening was effective under the natural epiphytotic condition. Subedi et al. (2020) also reported SB screening is effective under natural epiphytotic conditions at the present experiment site.

Table 1. Analysis of variation of the spot blotch disease - area under disease progress curve (AUDPC) of 342 barley genotypes during 2016, 2017 and 2018.

\begin{tabular}{lllll}
\hline \multicolumn{1}{c}{ Source of variation } & \multicolumn{2}{c}{ df } & \multicolumn{2}{c}{ MSS } \\
\hline & & 2016 & 2017 & 2018 \\
\cline { 2 - 4 } Blocks (unadjusted) & 16 & 207621 & 994235 & 263370 \\
Entries (adjusted) & 341 & $160098^{* * *}$ & $112087^{* * *}$ & $115242^{* * *}$ \\
Check & 1 & 24881 & $52773^{*}$ & $553866^{* * *}$ \\
Check + Check vs. Augmented & 340 & $160496^{* * *}$ & $112262^{* * *}$ & $113952^{* * *}$ \\
Residuals & 16 & 8377 & 7405 & 4777 \\
\hline
\end{tabular}

$*=$ significant $(\mathrm{p} \leq 0.05) ;{ }^{* * *}=$ highly significant $(\mathrm{p} \leq 0.001) ; \mathrm{df}=$ degree of freedom; MSS=mean sum of square 
In 2016, about $8 \%(\mathrm{n}=28)$ genotypes were resistant, $31 \%$ $(\mathrm{n}=105)$ genotypes were moderately resistant, $29 \%(\mathrm{n}=98)$ were moderately susceptible and $32 \%(n=109)$ were susceptible to SB. The check varieties Bonus and Solu Uwa had a susceptible type of reaction with the mean AUDPC value of 1276.7 and 1222.6 , respectively. In 2017, only one genotype (AM-321) showed a resistant reaction. There were 42 genotypes with MR reaction, 136 genotypes with $\mathrm{MS}$ reaction and 161 with $\mathrm{S}$ type of reaction. The number of susceptible genotypes were higher as compared to 2016 and 2018. The check variety Bonus (AUDPC=1212.8) and Solu Uwa (AUDPC=1134.0) were susceptible to SB. In 2018, about 20\% $(\mathrm{n}=69)$ genotypes showed MR type of reaction, about $38 \%(\mathrm{n}=132) \mathrm{MS}$ type of reaction, and about $40 \%(\mathrm{n}=139)$ showed $\mathrm{S}$ types of reaction. In this year, none of the genotypes had a $\mathrm{R}$ type of disease reaction. The check varieties Bonus and Solu Uwa were susceptible with the AUDPC value 1179.4 and 1434.6, respectively.

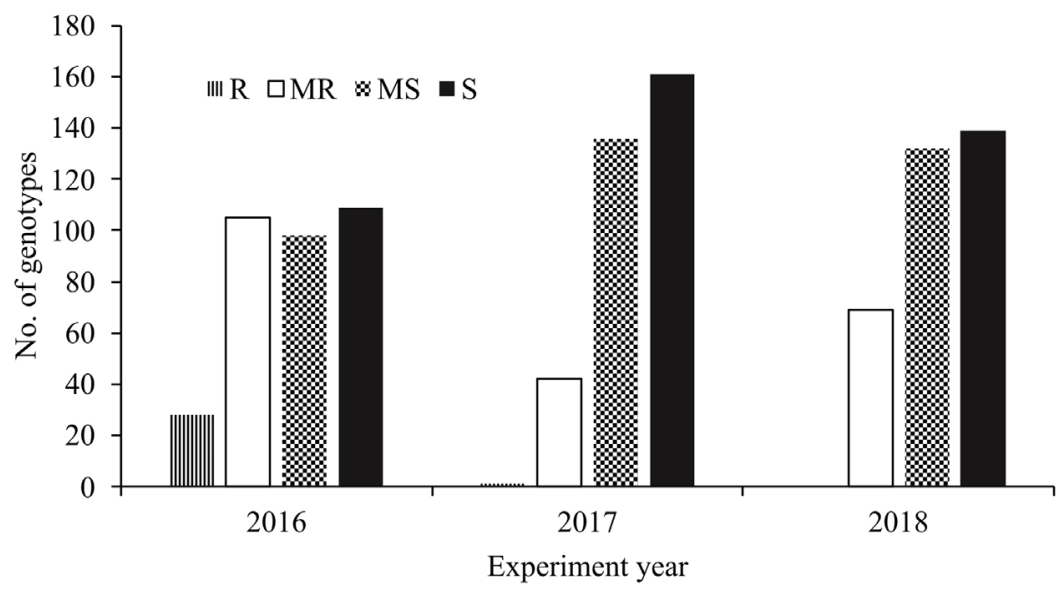

Figure 2. Frequency distribution of spot blotch reaction of 342 barley genotypes evaluated at Rampur, Chitwan under natural epiphytotic conditions in 2016, 2017 and 2018. Resistant (R), Moderately Resistant (MR), Moderately Susceptible (MS) and Susceptible (S).

The barley genotypes that have practical value for SB resistance breeding ( $\mathrm{R}, \mathrm{MR}$ or $\mathrm{MS}$ type of reaction across years) are summarized in Table 2. Of these, three genotypes- AM-128 (mean AUDPC=358), AM-188 (mean AUDPC=385) and AM-321 (mean AUDPC=270) showed a higher level of SB resistance. There were seven genotypes with $\mathrm{R}$ to $\mathrm{MR}$ reaction type and 24 genotypes with MR reaction type for at least two years (Table 2).

Table 2. Selected barley genotypes with resistant (R), moderately resistant (MR) or moderately susceptible (MS) type of spot blotch (SB) reaction across years (2016-2018).

\begin{tabular}{|c|c|c|c|c|c|c|c|c|}
\hline \multirow[b]{2}{*}{ Genotypes } & \multicolumn{2}{|c|}{ Year 2016} & \multicolumn{2}{|c|}{ Year 2017} & \multicolumn{2}{|c|}{ Year 2018} & \multicolumn{2}{|c|}{ Mean } \\
\hline & AUDPC & $\begin{array}{l}\text { Disease } \\
\text { reaction }\end{array}$ & AUDPC & $\begin{array}{c}\text { Disease } \\
\text { reaction }\end{array}$ & AUDPC & $\begin{array}{l}\text { Disease } \\
\text { reaction }\end{array}$ & AUDPC & $\begin{array}{l}\text { Disease } \\
\text { reaction }\end{array}$ \\
\hline AM-1 & 358 & $\mathrm{MR}$ & 420 & $\mathrm{MR}$ & 617 & MS & 465 & MR \\
\hline AM-4 & 358 & MR & 667 & MS & 660 & MS & 562 & MS \\
\hline AM-21 & 358 & MR & 562 & MS & 716 & MS & 545 & MS \\
\hline AM-24 & 426 & MR & 660 & MS & 580 & MS & 556 & MS \\
\hline AM-25 & 660 & MS & 562 & MS & 630 & MS & 617 & MS \\
\hline AM-30 & 500 & MS & 512 & MS & 716 & MS & 576 & MS \\
\hline AM-35 & 451 & MR & 685 & MS & 691 & MS & 609 & MS \\
\hline AM-42 & 407 & MR & 370 & MR & 593 & MS & 457 & MR \\
\hline AM-72 & 438 & MR & 562 & MS & 654 & MS & 551 & MS \\
\hline AM-82 & 309 & MR & 741 & MS & 580 & MS & 543 & MS \\
\hline AM-86 & 407 & MR & 568 & MS & 580 & MS & 519 & MS \\
\hline AM-87 & 660 & MS & 722 & MS & 531 & MS & 638 & MS \\
\hline
\end{tabular}


Journal of Cereal Research 13(1): 70-78

\begin{tabular}{|c|c|c|c|c|c|c|c|c|}
\hline AM-104 & 685 & MS & 691 & MS & 580 & MS & 652 & MS \\
\hline AM-105 & 272 & MR & 623 & MS & 630 & $\mathrm{MS}$ & 508 & MS \\
\hline AM-127 & 358 & MR & 617 & MS & 519 & MS & 498 & MR \\
\hline AM-128 & 235 & $\mathrm{R}$ & 432 & MR & 407 & MR & 358 & MR \\
\hline AM-130 & 407 & MR & 617 & MS & 630 & MS & 551 & MS \\
\hline AM-131 & 235 & $\mathrm{R}$ & 383 & MR & 636 & MS & 418 & MR \\
\hline AM-132 & 272 & MR & 580 & MS & 580 & MS & 477 & MR \\
\hline AM-142 & 660 & MS & 494 & MR & 673 & MS & 609 & MS \\
\hline AM-149 & 605 & MS & 586 & MS & 549 & MS & 580 & MS \\
\hline AM-156 & 309 & MR & 679 & MS & 383 & MR & 457 & MR \\
\hline AM-158 & 500 & MS & 642 & MS & 623 & MS & 588 & MS \\
\hline AM-160 & 309 & MR & 494 & MR & 654 & MS & 486 & MR \\
\hline AM-161 & 500 & MS & 457 & MR & 420 & MR & 459 & MR \\
\hline AM-162 & 235 & $\mathrm{R}$ & 568 & MS & 747 & MS & 516 & MS \\
\hline AM-164 & 235 & $\mathrm{R}$ & 531 & MS & 673 & MS & 479 & MR \\
\hline AM-166 & 500 & MS & 519 & MS & 358 & MR & 459 & MR \\
\hline AM-167 & 728 & MS & 407 & MR & 364 & MR & 500 & MS \\
\hline AM-168 & 667 & MS & 321 & MR & 617 & MS & 535 & MS \\
\hline AM-171 & 309 & MR & 401 & MR & 636 & MS & 449 & MR \\
\hline AM-174 & 358 & MR & 494 & MR & 685 & MS & 512 & MS \\
\hline AM-177 & 235 & $\mathrm{R}$ & 463 & MR & 679 & MS & 459 & MR \\
\hline AM-178 & 407 & MR & 253 & MR & 580 & MS & 414 & MR \\
\hline AM-180 & 636 & MS & 654 & MS & 636 & MS & 642 & MS \\
\hline AM-185 & 235 & $\mathrm{R}$ & 599 & MS & 667 & MS & 500 & MS \\
\hline AM-186 & 309 & MR & 568 & MS & 735 & MS & 537 & MS \\
\hline AM-187 & 580 & MS & 568 & MS & 500 & MR & 549 & MS \\
\hline AM-188 & 309 & MR & 401 & MR & 444 & MR & 385 & MR \\
\hline AM-198 & 358 & MR & 580 & MS & 549 & MS & 496 & MR \\
\hline AM-200 & 716 & MS & 383 & MR & 457 & MR & 519 & MS \\
\hline AM-201 & 235 & $\mathrm{R}$ & 580 & MS & 512 & MS & 442 & MR \\
\hline AM-202 & 660 & MS & 432 & MR & 654 & MS & 582 & MS \\
\hline AM-204 & 235 & $\mathrm{R}$ & 457 & MR & 580 & MS & 424 & MR \\
\hline AM-208 & 302 & MR & 432 & MR & 568 & MS & 434 & MR \\
\hline AM-211 & 235 & $\mathrm{R}$ & 284 & MR & 580 & MS & 366 & MR \\
\hline AM-212 & 580 & MS & 444 & MR & 549 & MS & 525 & MS \\
\hline AM-213 & 272 & MR & 648 & MS & 500 & MR & 473 & MR \\
\hline AM-215 & 691 & MS & 605 & MS & 432 & MR & 576 & MS \\
\hline AM-219 & 235 & $\mathrm{R}$ & 580 & MS & 562 & MS & 459 & MR \\
\hline AM-220 & 660 & MS & 667 & MS & 617 & MS & 648 & MS \\
\hline AM-222 & 580 & MS & 451 & MR & 383 & MR & 471 & MR \\
\hline AM-224 & 660 & MS & 556 & MS & 463 & MR & 560 & MS \\
\hline AM-225 & 272 & MR & 512 & MS & 605 & MS & 463 & MR \\
\hline AM-226 & 426 & MR & 617 & MS & 722 & MS & 588 & MS \\
\hline AM-230 & 358 & MR & 710 & MS & 611 & MS & 560 & MS \\
\hline AM-234 & 500 & MS & 568 & MS & 525 & MS & 531 & MS \\
\hline
\end{tabular}


Screening global set of barley germplasm for resistance to spot blotch disease in the warm-humid plains of Nepal

\begin{tabular}{|c|c|c|c|c|c|c|c|c|}
\hline AM-236 & 235 & $\mathrm{R}$ & 525 & MS & 364 & MR & 374 & MR \\
\hline AM-238 & 309 & MR & 654 & MS & 265 & MR & 409 & MR \\
\hline AM-246 & 309 & MR & 593 & $\mathrm{MS}$ & 735 & $\mathrm{MS}$ & 545 & MS \\
\hline AM-249 & 407 & MR & 679 & MS & 383 & MR & 490 & MR \\
\hline AM-250 & 235 & $\mathrm{R}$ & 660 & MS & 383 & MR & 426 & MR \\
\hline AM-251 & 272 & MR & 642 & MS & 475 & MR & 463 & MR \\
\hline AM-254 & 630 & MS & 438 & MR & 525 & MS & 531 & MS \\
\hline AM-256 & 562 & MS & 704 & MS & 642 & MS & 636 & MS \\
\hline AM-257 & 377 & MR & 642 & MS & 494 & MR & 504 & MS \\
\hline AM-261 & 389 & MR & 531 & $\mathrm{MS}$ & 407 & MR & 442 & MR \\
\hline AM-262 & 531 & MS & 679 & MS & 623 & MS & 611 & MS \\
\hline AM-264 & 481 & MR & 654 & MS & 512 & MS & 549 & MS \\
\hline AM-265 & 407 & MR & 617 & MS & 531 & MS & 519 & MS \\
\hline AM-266 & 549 & MS & 444 & MR & 623 & MS & 539 & MS \\
\hline AM-267 & 358 & MR & 580 & MS & 654 & MS & 531 & MS \\
\hline AM-268 & 660 & MS & 512 & MS & 636 & MS & 603 & MS \\
\hline AM-270 & 642 & MS & 543 & MS & 500 & MR & 562 & MS \\
\hline AM-271 & 500 & MS & 617 & MS & 457 & MR & 525 & MS \\
\hline AM-279 & 667 & MS & 568 & MS & 457 & MR & 564 & MS \\
\hline AM-283 & 358 & MR & 494 & MR & 716 & MS & 523 & MS \\
\hline AM-284 & 272 & MR & 605 & MS & 580 & MS & 486 & MR \\
\hline AM-285 & 630 & MS & 562 & MS & 364 & MR & 519 & MS \\
\hline AM-286 & 235 & $\mathrm{R}$ & 611 & MS & 605 & $\mathrm{MS}$ & 484 & MR \\
\hline AM-291 & 309 & MR & 562 & $\mathrm{MS}$ & 512 & $\mathrm{MS}$ & 461 & MR \\
\hline AM-307 & 580 & MS & 642 & MS & 667 & MS & 630 & MS \\
\hline AM-309 & 500 & MS & 420 & MR & 580 & MS & 500 & MS \\
\hline AM-310 & 235 & $\mathrm{R}$ & 580 & MS & 716 & MS & 510 & MS \\
\hline AM-312 & 407 & MR & 568 & MS & 383 & MR & 453 & MR \\
\hline AM-315 & 407 & MR & 704 & MS & 469 & MR & 527 & MS \\
\hline AM-321 & 235 & $\mathrm{R}$ & 117 & $\mathrm{R}$ & 457 & MR & 270 & MR \\
\hline AM-322 & 407 & MR & 599 & $\mathrm{MS}$ & 414 & MR & 473 & MR \\
\hline AM-323 & 660 & MS & 673 & $\mathrm{MS}$ & 370 & MR & 568 & MS \\
\hline AM-327 & 272 & MR & 611 & MS & 432 & MR & 438 & MR \\
\hline AM-329 & 506 & MS & 537 & $\mathrm{MS}$ & 309 & MR & 451 & MR \\
\hline AM-330 & 235 & $\mathrm{R}$ & 660 & MS & 333 & MR & 409 & MR \\
\hline AM-334 & 660 & MS & 630 & MS & 475 & MR & 588 & MS \\
\hline AM-336 & 660 & MS & 512 & MS & 716 & $\mathrm{MS}$ & 630 & MS \\
\hline AM-339 & 574 & MS & 593 & MS & 512 & $\mathrm{MS}$ & 560 & MS \\
\hline AM-340 & 481 & MR & 543 & MS & 438 & MR & 488 & MR \\
\hline $\begin{array}{l}\text { Bonus } \\
\text { (Check) }\end{array}$ & 1277 & $\mathrm{~S}$ & 1213 & $\mathrm{~S}$ & 1179 & $\mathrm{~S}$ & 1223 & $\mathrm{~S}$ \\
\hline $\begin{array}{l}\text { Solu Uwa } \\
\text { (Check) }\end{array}$ & 1223 & $\mathrm{~S}$ & 1134 & $\mathrm{~S}$ & 1435 & $\mathrm{~S}$ & 1264 & $\mathrm{~S}$ \\
\hline
\end{tabular}

AUDPC $=$ Area Under Disease Progress Curve

Spot blotch of barley usually appearing in a warmer climate barley was initially grown mostly in the high-altitude cool was not regarded as an important pathogen in Nepal where areas. However, the pathogen became important after barley 
acreages started to expand in the warmer Terai plains and the disease is now considered a major challenge to barley production. The SB resistance level of barley varieties bred for the cool environments is unsatisfactory in the warm humid areas and require a significant improvement (Gyawali et al., 2018). The current barley improvement activities in Nepal are primarily targeted for the cool areas and therefore need additional sources of SB resistance to incorporate satisfactory level of SB resistance in future barley varieties for the warm-humid areas.

Three years of disease screening results revealed variation for spot blotch resistance in the ICARDA germplasm (Association mapping panel- AM-2014). About 27\% genotypes showed resistant to moderately susceptible type of reaction across the years (Table 2), indicating that the germplasm can be utilized for barley improvement program in Nepal. Previous study also showed variation of ICARDA barley germplasm for SB resistance in India and Tunisia (Visioni et al., 2020; Kumar et al., 2020). The genotypes identified in this study viz., AM-128, AM-188 and AM321 that have high level of resistance and stable response to SB can be immediately utilized by the national barley improvement program. Further screening of the ICARDA germplasm (AM-2014) used in this study in different locations of Terai region of Nepal will provide a conclusive information regarding the germplasm reaction to the prevalent $\mathrm{SB}$ races in Nepal. Such information will be useful to the Nepalese and international barley improvement programs aiming to develop improved disease resistant varieties for the warm humid environment.

\section{Acknowledgement}

This research was funded by International Center for Agricultural Research in the Dry Areas (ICARDA) and Nepal Agricultural Research Council (NARC), Nepal. The authors acknowledge National Maize Research Program, Rampur, Chitawan for providing research field and support staffs. Sincere thanks go to Dr. R Amezrou (ICARDA) and his staff for providing barley germplasm and other logistic support.

\section{Conflict of interest}

The authors declare that they have no conflict of interest.

\section{Compliance with ethical standards}

The authors have followed ethical norms accepted by international scientific community and made every endeavor to prevent any infringements of the norms. No human participants or animals were used in the experiment.

\section{Author contribution}

BBP - Preparation of research proposal, carried out field experiments, data collection, data analysis, interpretation of the results and manuscript preparation; MMP - guided for research proposal preparation, field experimentation, data analysis and thorough guidance for manuscript preparation; SKG \& DBT - guided for research proposal preparation, field experimentation, manuscript preparation; HKM - guided for field data collection; TRR, PA \& ST helped to collect disease data; RPSV - helped for project proposal preparation and SG - project design, helped in germplasms import to Nepal, guided for field research, data collection, data analysis, interpretations of the data, results and manuscript preparation.

\section{References}

1. Akhavan A, TK Turkington, H Askarian, A Tekauz A, K Xi,JR Tucker, HR Kutcher and SE Strelkov. 2016. Virulence of Pyrenophora teres populations in western Canada. Canadian Journal of Plant Pathology 38:183196. doi: 10.1080/07060661.2016.1159617.

2. Amezrou R, S Gyawali, L Belqadi, S Chao, M Arbaoui, S Mamidi and RPS Verma. 2017. Molecular and phenotypic diversity of a worldwide ICARDA spring barley collection. Genetic Resources and Crop Evolution 65:255-269 https://doi.org/10.1007/s10722017-0527-z.

3. Baik BK and SE Ullrich. 2008. Barley for Food: Characteristics, improvement and renewed interest. Journal of Cereal Science 48:233-242. http://dx.doi. org/10.1016/j.jcs.2008.02.002.

4. Bocianowski J, A Tratwal and Nowosad K. 2020. Genotype by environment interaction for area under the disease-progress curve (AUDPC) value in spring barley using additive main effects and multiplicative interaction model. Australasian Plant Pathology 49:525529. https://doi.org/10.1007/s13313-020-00723-7.

5. Bovill J, A Lehmensiek, MW Sutherland, GJ Platz, T Usher, J Franckowiak and E Mace. 2010. Mapping spot blotch resistance genes in four barley populations. Molecular Breeding 26:653-666. DOI10.1007/s11032-010-9401-9. 
Screening global set of barley germplasm for resistance to spot blotch disease in the warm-humid plains of Nepal

6. Cane SF and JG Hampton. 1990. The effects of Bipolaris sorokiniana on barley seed quality. Australasian Plant Pathology. 19(1): 26-29.

7. Devi HM, S Mahapatra and S Das. 2019. Management of spot blotch of wheat using inducer chemicals under field conditions. Journal of Cereal Research 11(2):152-158 doi.org/10.25174/2249-4065/2019/86740.

8. FAOSTAT. 2019. World Agricultural Statistics. Retrieved from http://www.fao.org/ faostat/en/\#data on 22 December 2020.

9. Gupta PK, NK Vasistha, R Aggarwal and A Joshi. 2017. Biology of B. sorokiniana (Cochliobolus sativus) in the genomics era. Journal of Plant Biochemistry and Biotechnology 27:123-138. doi 10.1007/s 13562-0170426-6.

10. Gyawali S, C Shiaoman, SS Vaish, SP Singh S Rehman, Vishwakarma SR and RPS Verma. 2018. Genome wide association studies (GWAS) of spot blotch resistance at the seedling and the adult plant stages in a collection of spring barley. Molecular Breeding 38 article no. 62 https://doi.org/10.1007/ s11032-018-0815-0.

11. Idehen E, Y Tang and S Sang. 2017. Bioactive phytochemicals in barley. Journal of Food E Drug Analysis 25(1):148-161. https://doi.org/10.1016/j. jfda.2016.08.002.

12. Joshi AK, GO Ferrara, J Crossa, G Singh, RC Sharma, R Chand and R Parsad. 2007. Combining superior agronomic performance and terminal heat tolerance with resistance to spot blotch (Bipolaris sorokiniana) of wheat in the warm humid Gangetic Plains of South Asia. Field Crops Research 103:53-61. doi: 10.1016/j. fcr.2007.04.010.

13. Knight N, G Platz, A Lehmensiek and MW Sutherland. 2010. An investigation of genetic variation among Australian isolates of Bipolaris sorokiniana from different cereal tissues and comparison of their ability to cause spot blotch on barley. Australasian Plant Pathology 39(3):1-16. doi: 10.1071/AP09082.

14. Kumar M, R Chand and RS Dubey. 2014. Effect of Tricyclazole on morphology, virulence, and enzymatic alterations in pathogenic fungi Bipolaris sorokiniana for management of spot blotch disease in barley. World Journal of Microbiology and Biotechnology 31:23-35. doi 10.1007/s11274-014-1756-3.

15. Kumar V, PS Shekhawat, SR Vishwakarma, SC Bharadwaj, S Kumar, AS Kharub and GP Singh. 2020. Identification of resistant sources against spot blotch and stripe rust of barley. Journal of Cereal Research 12(1):50-54. http://doi.org/10.25174/25822675/2020/88973.

16. Manandhar HK, RD Timila, S Sharma, S Joshi, S Manandhar, SB Gurung, S Sthapit, E Palikhey, A Pandey A, BK Joshi, G Manandhar, D Gauchan, DI Jarvis and BR Sthapit. 2017. A field guide for identification and scoring methods of diseases in the mountain crops of Nepal. pp 52-55. NARC, DoA, LI-BIRD and Bioversity International, Nepal.

17. Mendiburu F de. 2020. 'agricolae' Statistical Procedures for Agricultural Research. R Package Version 1.3-3: https://cran.r-project.org/web/packages/ agricolae/index.html

18. MALD. 2019. Statistical Information on Nepalese Agriculture. Agri-Business Promotion and Statistics Division, Ministry of Agriculture and Livestock Development, Singha Durbar, Kathmandu, Nepal.

19. Mudi N, S Mahapatra and S Das. 2010. Screening of barley cultivars against Helminthosporium sativum and the stability of disease reaction and yield. Indian Phytopathology 63(1):91-93.

20. Mudi N, S Mahapatra and S Das. 2016. Assessment of Helminthosporium blight resistance in barley using disease stress tolerance Index. Indian Phytopathology 69(1):24-31.

21. NARC. 2020. Released crop varieties in Nepal. Nepal Agricultural Research Council, Singh Darabar Plaza, Kathamndu, Nepal. www.narc.gov.np.

22. Newton AC, AJ Flavell, TS George, P Leat, B Mullholland, L Ramsay, Revoredo-Giha C, Russell J, Steffenson BJ, Swanston JS, Thomas WTB, Waugh R, White PJ and Bingham IJ. 2011. Crops that feed the world. Barley: a resilient crop? Strengths and weaknesses in the context of food security. Food Security 3:141-149. https://doi.org/10.1007/s12571011-0126-3.

23. Pandey SP, S Sharma, R Chand, P Shahi and AK Joshi. 2008. Clonal variability and its relevance in 
the generation of new pathotypes in the spot blotch pathogen, Bipolaris sorokiniana. Current Microbiology 156:33-41.

24. Patial M, D Pal, R Kapoor and KK Pramanick. 2018. Inheritance and combining ability of grain yield in half diallel barley population. Wheat and Barley Research 10(3): 173-178.

25. Pokharel BB, K Baral, KB Koirala, S Subedi, R Bhattarai, KP Pokharel, B Ghimire, G KC, AP Paudel, AP Paudel, A Timilsina, HK Prasai, BN Adhikari and B Khanal. 2016. Varietal investigation on barley under different agri-ecological regions of Nepal. pp 251-259. In: Giri Y P et et al. (eds) Proceedings of the $29^{\text {th }}$ National Winter Crops Workshop, held on 11-12 June 2014 at Regional Agriculture Research Station, Lumle, Kaski, Nepal. Nepal Agricultural Research Council, ISSN 2542-2871. https://www.narc.gov.np.

26. R Core Team. 2021. R: A language and environment for statistical computing. R Foundation for Statistical Computing, Vienna, Austria. https://www.R-project. org/.

27. Saari EE and Prescott JM. 1975. A scale for appraising the foliar intensity of wheat disease. Plant Disease Reporter 59: 377-380.

28. Singh S, H Singh, A Sharma, M Meeta, B Singh, N Joshi, P Grover, A Yassin and S Kumar. 2014. Inheritance of spot blotch resistance in barley (Hordeum vulgare L.). Canadian Journal of Plant Science 94:1-7 DOI: 10.4141/cjps2013-153.
29. Singh T, VK Mishra, LC Prasad and R Chand. 2014. Variation for infection response to Bipolaris sorokiniana and identification of trait specific sources in barley (Hordeum vulgare L.) germplasm. Australian Journal of Crop Science 8(6): 909-915.

30. Subedi S, S Neupane, S Gurung, A Raymajhi and L Oli. 2020. Evaluation of barley genotypes against spot blotch disease in inner Terai region of Nepal. Journal of Nepal Agricultural Research Council 6:70-78.

31. Turan R, BS Tyagi, A Sharma, G Singh, V Singh and A Ojha. 2017. Assessment of genetic variability and correlation among agro-morphological traits and spot blotch disease in a RIL population of wheat. Journal of Wheat Research 9(2): 108-114. doi.org/ 10.25174/22494065/2017/73499.

32. Tyagi V, SR Jacob, K Gupta and P Brahmi. 2020. Status of introduction and conservation in barley (Hordeum vulgare L.). Journal of Cereal Research 12(1): 1318. http://doi.org/10.25174/2582-2675/2020/83213.

33. Visioni A, S Rehman, SS Vaish, R Vishwakarma, S Gyawali, AM Al-Abdallat and RPS Verma. 2020. Genome-Wide Association Mapping of Spot Blotch Resistance at Seedling and Adult Plant Stages in Barley. Frontiers in Plant Science 11:1-16. https://doi. org/10.3389/fpls.2020.00642.

34. Wang R, Y Leng, S Ali, M Wang and S Zhong. 2017. Genome-wide association mapping of spot blotch resistance to three different pathotypes of Cochliobolus sativus in the USDA barley core collection. Molecular Breeding 37(4):44-58 doi.10.1007/s11032-017-0626-8. 